\title{
Can the Sasang Constitutional Type Trait Act as an Independent Risk Factor for Dyslipidemia?
}

\author{
Jiwon Lee*, Hyunsu Jang*, Byungjoo Park, Euiju Lee, Byunghee Koh, Junhee Lee \\ Department of Sasang Constitutional Medicine, College of Korean Medicine, Kyung Hee University
}

Received: December 2, 2014 Revised: December 15, 2014 Accepted: December 15, 2014

Correspondence to: Junhee Lee Department of Sasang Constitutional Medicine, College of Korean Medicine, Kyung Hee University, 23

Kyungheedae-ro, Dongdaemun-gu, Seoul 130-872, Korea

Tel: +82-2-958-9280

Fax: +82-2-958-9234

E-mail: ssljh@daum.net

*These authors have contributed

equally to this study.

Copyright $@ 2014$ by The Society of Korean

Medicine for Obesity Research
Objectives: This study was designed to investigate the correlation between Sasang constitution and dyslipidemia and the possibility that Sasang constitution can be a risk factor of dyslipidemia. Methods: This study was a retrospective cross-sectional study based on chart review. Seventeen thousand sixty-nine charts which were collected from May 2007 to June 2010 in International Healthcare Service Center, Kyung Hee University Medical Center, were reviewed for the study. Fifteen thousand two hundred fifty charts including Sasang constitutional diagnosis and lipid profiling were selected and we examined the correlation between Sasang constitution and dyslipidemia.

Results: After adjusted for body mass index, the levels of total cholesterol and triglyceride were highest in Taeeum group, and lowest in Soeum group. High-density lipoprotein was highest in Soeum group, and lowest in Taeeum group. After adjusted for age, sex, and body mass index, the odds ratios for 'high triglyceride' were 1.716 (1.411 2.087) in Soyang group and 2.021 (1.650 2.475) in Taeeum group compared to Soeum group. The odds ratio for "high low-density lipoprotein' was $1.229(1.006 \sim 1.501)$ in Soyang group compared to Soeum group. The odds ratios for 'low high-density lipoprotein' were $1.195(1.033 \sim 1.381)$ in Soyang group and 1.414 (1.212 1.649) in Taeeum group compared to Soeum group.

Conclusions: The lipid profiles and dyslipidemic risk differed across constitutional types, showing constitution type-specific patterns, so that we could infer the possibility that Sasang constitutional types can be a risk factor of dyslipidemia.

Key Words: Dyslipidemias, Sasang constitution

\section{Introduction}

Dyslipidemia refers to the abnormalities in lipoprotein homeostasis that is clinically important as a contributor to the development of atherosclerosis and its sequelae, most notably coronary heart disease (CHD) and cerebrovascular disease. Reflecting its clinical significance, the third report of the National Cholesterol Education Program (NCEP) Expert Panel on Detection, Evaluation, and Treatment of High Blood Cholesterol in Adults (Adult Treatment Panel III, or ATP III) had outlined the recommendations for cholesterol testing and management, placing a strong emphasis on the adjustment of the overall strategy and intensity of therapy according to the individual patient's global cardiovascular risk ${ }^{1-3)}$.

The dyslipidemic risk in an individual can be affected by many factors, including his genetic predisposition and the environmental influences. Recent studies have demonstrated that racial and ethnic groups vary in the baseline risk for dyslipidemia ${ }^{4-6}$. Ethnicity can be important in that lipid profiles and the sequelae of dyslipidemia can manifest differently across ethnic groups, implicating a need for an ethnically adjusted management strategy. It can also point out the population group that may require a stricter lipid control in light of their ethnicity-based disadvantage involving other vascular risk factors ${ }^{7-9)}$.

Though targeting lipid control interventions based on 
ethnic groups may contribute to a more time- and cost-efficient strategy, this may still not be specific enough in clinical settings to set up a personalized lipid control plan, considering that individuals show different susceptibilities even within the same ethnic and racial groups. In response to the demand for a more patient-specific method of identifying and predicting the dyslipidemic risk, some have suggested a new approach to this matter that is more finely attuned to the constitutional make-up of each individual. Such constitution-based methodology could offer a new guideline that takes personal traits into account without being too cumbersome to implement ${ }^{10}$.

One of the typological theories rooted in the constitution-based approach is the Sasang Constitutional Typology, which categorizes individuals into one of the four Sasang constitution types (namely the Taeyang [TY], Soyang [SY], Taeeum [TE], and Soeum [SE] types) based on mental characteristics, physical traits, and physiopathological patterns. The current researches in Sasang Constitutional Typology encompass diagnostics, physiology and pathology, and therapeutics and preventive healthcare ${ }^{11-13)}$. Also, recent evidence suggests that the Sasang constitution types can be a predictor of the risk for several conditions including insulin resistance, type 2 diabetes mellitus and hypertension ${ }^{14-16)}$.

In order to explore the potential of Sasang Constitutional Typology as a tool for assessing dyslipidemic patterns and risk, we have conducted a cross-sectional epidemiological study exploring the prevalence and risk rates for dyslipidemic profiles across the different Sasang constitutional types.

\section{Materials and Methods}

\section{Subjects}

The initial data pool was taken from Kyung Hee International Healthcare Service Center Health Exami-

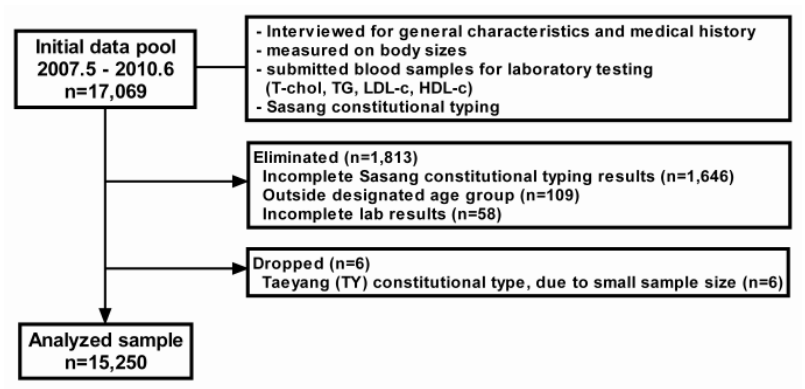

Fig. 1. Flow chart of the data selection. T-chol: total cholesterol, TG: triglyceride, LDL-C: low density lipoprotein cholesterol, HDL-C: high density lipoprotein cholesterol.

nation Database between May 2007 and June 2010, during which 17,069 men and women visited the clinic for routine physical check-up. They were interviewed for general characteristics and medical history, were measured on body sizes, submitted blood samples for laboratory testing (total cholesterol [T-chol], triglyceride [TG], low density lipoprotein cholesterol [LDL-chol], and high density lipoprotein cholesterol [HDL-chol]), and were given Sasang constitutional typing. The initial data pool was sieved for completeness of Sasang constitution typing results, leaving 15,423 subjects. Participants were also eliminated if out of the designated age range (21 80 years) or found to have missing data (58 were excluded due to incomplete laboratory results; 109 were excluded for being outside the age limit). The 6 individuals who were typed as the TY constitutional type were determined as a statistical minority and were therefore dropped from the study. In the end, the data sets of 15,250 subjects were examined for analysis (Fig. $1)$.

\section{Ethical considerations}

All the investigations herein described were conducted in full accordance with the ethical standards of the World Medical Association Declaration of Helsinki of 1975, as revised in 2004. The Institutional Review Board of Kyung Hee University Oriental Hospital had given full approval and authorization of this study (KOMCIRB- 
2011-40).

\section{Anthropometric methods and body mass index (BMI) calculation}

Height and weight were obtained in light clothing (to the nearest $0.1 \mathrm{~cm}$ or $0.1 \mathrm{~kg}$ ). BMI was calculated using the equation: BMI=weight $(\mathrm{kg}) /$ height $^{2}\left(\mathrm{~m}^{2}\right)$. Waist circumference (WC) was measured horizontally at the mid-point between the inferior border of rib cage and the superior border of iliac crest.

\section{Blood sampling and testing}

Fasting blood samples were collected from an antecubital vein after at least 12 hours of fasting. The serum T-chol, TG, LDL-chol, and HDL-chol levels were then measured using the Hitachi 7600 Automatic Analyzer (Hitachi Co., Tokyo, Japan).

\section{Sasang constitutional typing}

As the first step in the Sasang constitutional typing process, the examinees were asked to complete the revised Questionnaire for the Sasang Constitution Classification II (QSCC II+) ${ }^{17)}$. The Sasang constitutional medicine specialists interviewed each examinee and decided on his/her Sasang constitutional type based on the QSCC II+ results and comprehensive assessment. The Sasang constitutional medicine specialists were qualified traditional Korean medical doctors licensed by the Korean government, with six years of traditional Korean medicine training, minimum two years of training in Sasang constitutional medicine.

The QSCC II+ is a questionnaire widely used in constitutional typing with an acceptable level of reliability and validity that had been originally developed in order to confer greater objectivity to the process of constitutional typing. During constitutional assessment, the Sasang specialist collects all pertinent information on the subject's mental characteristics, physical traits, physiological patterns, and pathological developments in order to determine most accurately the subject's constitutional type as one of the four Sasang constitutional types: the TY, SY, TE, or SE type.

\section{Clinical definitions for dyslipidemia and overweight/obesity}

The cutoff values of the dyslipidemic indices were taken from the NCEP-ATP III classification, adopting the 'high' values for T-chol, LDL-chol, and TG and the 'low' value for HDL-chol: $\mathrm{T}-$ chol $\geq 240 \mathrm{mg} / \mathrm{dL}$ as high T-chol', TG $\geq 200 \mathrm{mg} / \mathrm{dl}$ as 'high TG', LDL-chol $\geq 160$ $\mathrm{mg} / \mathrm{dl}$ as 'high LDL-chol', and HDL-chol $<40 \mathrm{mg} / \mathrm{dL}$ as "low HDL-chol"1).

The BMI cutoff points for determining overweight/ obesity were taken from the World Health Organization recommendation for the Asian-Pacific populations classifying $\mathrm{BMI}<18.5$ as 'underweight', $18.5 \leq \mathrm{BMI}<23.0$ as 'normal weight', $23.0 \leq \mathrm{BMI}<25.0$ as 'overweight', and $\mathrm{BMI} \geq 25.0$ as 'obese' ${ }^{18)}$.

\section{Analysis and statistical methods}

The data from the 15,250 subjects was first examined for general characteristics and clinical parameters, which were compared between the male and female subjects by independent sample $\mathrm{t}$-test and chi-square test.

Also, the gender distribution (male or female) and BMI profiles (underweight, normal, overweight, obese) were explored across different Sasang types, in which the differences were detected by chi-square test. To further explore the association between dyslipidemia, weight status, and Sasang constitutional types, the male and female groups were each stratified into BMI tertiles (lower tertile, middle tertile, and upper tertile) within the respective gender group, and the prevalence of each dyslipidemic index (high $\mathrm{T}$-chol, high $\mathrm{TG}$, high LDL-chol, low HDL-chol) was examined across the Sasang constitutional groups for each BMI tertile, in 
which the differences were detected by chi-square test. The constitutional group $\times$ BMI tertile group (within each gender) interaction was tested using two-way ANOVA, and if no interaction effect was detected, post hoc multiple comparison by Scheffe's method was performed to compare the different constitutional types for each lipid profile index (T-chol, TG, LDL-chol, HDL-chol) (group-by-group interaction for TG was analyzed after log transformation of TG values).

Finally, to assess the influence of the Sasang constitutional type on dyslipidemic risk, the odds ratio for each dyslipidemic index (high T-chol, high TG, high LDL-chol, low HDL-chol) were compared across different Sasang constitutional groups by binary logistic regression analysis (after adjusting for age, sex, and $\mathrm{BMI}$ ), taking either the SE or SY group as the reference group.

For all statistical analysis, the SPSS ver. 13.0 software for Windows (SPSS Inc., Chicago, IL, USA) was used. $\mathrm{P}$-values $<0.05$ were considered to be statistically significant. Age, anthropometric values, blood test results, and results of Sasang constitutional typing were expressed as 'means \pm standard deviation' or 'number of subjects (\%)'.

\section{Results}

\section{General characteristics and clinical parameters}

The general characteristics and clinical parameters of the subjects are displayed in Table 1. Differences between the male and female groups were detected in age, body sizes (height, weight, BMI, WC), and lipid profile (T-chol, TG, LDL-chol, HDL-chol). The Sasang-type distribution also differed between the male and female groups, showing prevalence distribution of $\mathrm{TE}>\mathrm{SY}>\mathrm{SE}$ in men and TE $>\mathrm{SE}>\mathrm{SY}$ in women.

\section{Gender and BMI distribution across different Sasang constitution types}

As shown in Table 2, 3, male prevalence was found to differ among the different Sasang constitution types. A difference in BMI distribution (underweight, normal weight, overweight, obese) was also detected among the different constitution type, prevalence rates peaking in the normal weight group in the SY type (52.13\%), obese group in the TE type (60.78\%), and normal weight group in the SE type (71.11\%).

Table 1. General Characteristics and Clinical Parameters in Men and Women

\begin{tabular}{|c|c|c|c|}
\hline Variable & Men $(n=7,929)$ & Women $(n=7,321)$ & Total $(n=15,250)$ \\
\hline Age (yr) & $45.86 \pm 10.52$ & $45.55 \pm 11.22$ & $45.71 \pm 10.87$ \\
\hline Height $(\mathrm{cm})^{a}$ & $170.23 \pm 5.85$ & $157.70 \pm 5.62$ & $164.22 \pm 8.49$ \\
\hline Weight $(\mathrm{kg})^{\mathrm{a}}$ & $71.35 \pm 9.99$ & $57.09 \pm 7.94$ & $64.50 \pm 11.53$ \\
\hline Body mass index $\left(\mathrm{kg} / \mathrm{m}^{2}\right)^{a}$ & $24.59 \pm 2.93$ & $22.98 \pm 3.17$ & $23.82 \pm 3.15$ \\
\hline Waist circumference $(\mathrm{cm})^{a}$ & $86.48 \pm 7.59$ & $79.39 \pm 8.73$ & $83.08 \pm 8.89$ \\
\hline $\mathrm{T}-\mathrm{chol}(\mathrm{mg} / \mathrm{dl})^{\mathrm{a}}$ & $196.36 \pm 33.34$ & $192.05 \pm 33.97$ & $194.29 \pm 33.71$ \\
\hline $\mathrm{TG}(\mathrm{mg} / \mathrm{dl})^{\mathrm{a}}$ & $152.83 \pm 101.58$ & $102.24 \pm 63.11$ & $128.54 \pm 88.97$ \\
\hline LDL-chol (mg/dl) $)^{\mathrm{a}}$ & $118.11 \pm 30.23$ & $111.97 \pm 30.89$ & $115.17 \pm 30.70$ \\
\hline $\mathrm{HDL}-\mathrm{chol}(\mathrm{mg} / \mathrm{dll})^{\mathrm{a}}$ & $47.15 \pm 11.85$ & $55.39 \pm 14.01$ & $51.11 \pm 13.57$ \\
\hline \multicolumn{4}{|l|}{ Sasangconstitutional type ${ }^{b}$} \\
\hline SY type & 2,997 (37.80) & $2,004(27.37)$ & $5,001(32.79)$ \\
\hline TE type & $3,941(49.70)$ & $3,106(42.43)$ & $7,047(46.21)$ \\
\hline SE type & $991(12.50)$ & $2,211(30.20)$ & $3,202(21.00)$ \\
\hline
\end{tabular}

Values are presented as mean \pm standard deviation or number (\%).

T-chol: total cholesterol, TG: triglyceride, LDL-chol: low density lipoprotein cholesterol, HDL-chol: high density lipoprotein cholesterol, SY: Soyang, TE: Taeeum, SE: Soeum.

${ }^{a}$ Difference detected by independent sample t-test $(P<0.05)$. ${ }^{b}$ Difference detected by chi-square test $(P<0.05)$. 
Jiwon Lee, et al: Sasang Constitutional Type as a Risk factor for Dyslipidemia

Table 2. Gender and BMI Distribution, and Prevalence of Dyslipidemic Index across the Different Sasang Constitution Types

\begin{tabular}{|c|c|c|c|c|}
\hline \multirow{2}{*}{ Variable } & \multicolumn{3}{|c|}{ Constitutional types } & \multirow{2}{*}{ P-value } \\
\hline & SY type $(n=5,001)$ & TE type $(n=7,047)$ & SE type $(n=3,202)$ & \\
\hline Male distribution & 2,997 (59.93) & $3,941(55.92)$ & $991(30.95)$ & $<0.001^{a}$ \\
\hline $\mathrm{BMI}$ & & & & $<0.001^{a}$ \\
\hline Underweight & $111(2.22)$ & $9(0.13)$ & $383(11.96)$ & \\
\hline Normal weight & 2,607 (52.13) & $977(13.86)$ & $2,277(71.11)$ & \\
\hline Overweight & $1,501(30.01)$ & $1,778(25.23)$ & $425(13.27)$ & \\
\hline Obese & $782(15.64)$ & $4,283(60.78)$ & $117(3.65)$ & \\
\hline Lower BMI tertile ${ }^{b, c}$ & 2,284 & 586 & 2,213 & \\
\hline High T-chol & $136(5.95)$ & $32(5.46)$ & $103(4.65)$ & 0.151 \\
\hline High TG & $204(8.93)$ & $45(7.68)$ & $74(3.34)$ & $<0.001^{a}$ \\
\hline High LDL-chol & $128(5.60)$ & $33(5.63)$ & $71(3.21)$ & $<0.001^{a}$ \\
\hline Low HDL-chol & 341 (14.93) & $95(16.21)$ & $196(8.86)$ & $<0.001^{a}$ \\
\hline Middle BMI tertile & 2,024 & 2,220 & 838 & \\
\hline High T-chol & $203(10.03)$ & $202(9.10)$ & $70(8.35)$ & 0.325 \\
\hline High TG & $298(14.72)$ & 395 (17.79) & $46(5.49)$ & $<0.001^{a}$ \\
\hline High LDL-chol & $182(8.99)$ & $172(7.75)$ & $64(7.64)$ & 0.268 \\
\hline Low HDL-chol & $406(20.06)$ & $483(21.76)$ & $91(10.86)$ & $<0.001^{a}$ \\
\hline Upper BMI tertile & 693 & 4,241 & 151 & \\
\hline High T-chol & $92(13.28)$ & $579(13.65)$ & $20(13.25)$ & 0.957 \\
\hline High TG & $132(19.05)$ & $996(23.49)$ & $21(13.91)$ & $0.001^{a}$ \\
\hline High LDL-chol & $92(13.28)$ & 525 (12.38) & $19(12.58)$ & 0.803 \\
\hline Low HDL-chol & $155(22.37)$ & 1,263 (29.78) & $25(16.56)$ & $<0.001^{a}$ \\
\hline
\end{tabular}

Values are presented as number (\%) or number only.

SY: Soyang, TE: Taeeum, SE: Soeum, BMI: body mass index, T-chol: total cholesterol, TG: triglyceride, LDL-chol: low density lipoprotein cholesterol, HDL-chol: high density lipoprotein cholesterol.

${ }^{a}$ Difference detected across constitutional types by chi-square test. ${ }^{\mathrm{b}} \mathrm{BMI}$ tertile cutoff value within each gender group. Male: lower tertile, $\mathrm{BMI} \leq$ 23.298; middle tertile, 23.301 $\leq \mathrm{BMI} \leq 25.728$; upper tertile, 25.729 $\leq \mathrm{BMI}$. Female: lower tertile, $\mathrm{BMI} \leq 21.351$; middle tertile, $21.353 \leq \mathrm{BMI} \leq$ 24.002; upper tertile, $24.003 \leq \mathrm{BMI}$. 'Based on NCEP-ATP III criteria definition of dyslipidemia: T-chol $\geq 240 \mathrm{mg} / \mathrm{dl} ; \mathrm{TG} \geq 200 \mathrm{mg} / \mathrm{dl} ; \mathrm{LDL}$-chol $\geq$ $160 \mathrm{mg} / \mathrm{dl} ; \mathrm{HDL}-\mathrm{chol}<40 \mathrm{mg} / \mathrm{dl}$.

Table 3. Comparison of Lipid Profile across the Different Sasang Constitution Types

\begin{tabular}{|c|c|c|c|c|c|}
\hline Variable & SY type $(n=5,001)$ & TE type $(\mathrm{n}=7,047)$ & SE type $(n=3,202)$ & $\begin{array}{l}\text { Constitution type } \times \mathrm{BMI} \\
\text { group interaction }\end{array}$ & Post hoc comparison \\
\hline T-chol (mg/dl) & $193.21 \pm 32.96$ & $198.42 \pm 34.45$ & $186.90 \pm 31.79$ & No $(P=0.521)$ & $\begin{array}{c}<0.001^{\mathrm{a}} \\
\mathrm{TE}>\mathrm{SY}>\mathrm{SE}\end{array}$ \\
\hline $\mathrm{TG}(\mathrm{mg} / \mathrm{dl})^{\mathrm{b}}$ & $124.29 \pm 87.50$ & $148.31 \pm 96.68$ & $91.66 \pm 54.08$ & No $(P=0.055)$ & $\begin{array}{c}<0.001^{\mathrm{a}} \\
\mathrm{TE}>\mathrm{SY}>\mathrm{SE}\end{array}$ \\
\hline LDL-chol (mg/dl) & $113.99 \pm 30.36$ & $119.56 \pm 31.02$ & $107.34 \pm 28.73$ & Yes $(P=0.011)$ & - \\
\hline HDL-chol (mg/dl) & $52.04 \pm 13.74$ & $47.97 \pm 12.16$ & $56.57 \pm 14.28$ & No $(P=0.218)$ & $\begin{array}{c}<0.001^{\mathrm{a}} \\
\mathrm{TE}<\mathrm{SY}<\mathrm{SE}\end{array}$ \\
\hline
\end{tabular}

Values are presented as mean \pm standard deviation.

SY: Soyang, TE: Taeeum, SE: Soeum, BMI: body mass index, T-chol: total cholesterol, TG: triglyceride, LDL-chol: low density lipoprotein cholesterol, HDL-chol: high density lipoprotein cholesterol.

${ }^{a}$ Compared by two-way ANOVA (factor: Sasang constitutional type, BMI tertile group within each gender group) (post hoc multiple comparison by Scheffe's method). ${ }^{\text {b} A n a l y z e d ~ a f t e r ~ l o g a r i t h m i c ~ t r a n s f o r m a t i o n . ~}$

\section{Prevalence of each dyslipidemic index across the Sasang constitutional types after BMI stratification}

The subjects were stratified into BMI tertiles within each gender group as displayed in Table 2, 3, of which the cutoff BMI values for the lower, middle, and upper tertiles were $\mathrm{BMI} \leq 23.298$ for the lower tertile, $23.301 \leq$ $\mathrm{BMI} \leq 25.728$ for the middle tertile, and $25.729 \leq \mathrm{BMI}$ 
for the upper tertile in men, and $\mathrm{BMI} \leq 21.351$ for the lower tertile, $21.353 \leq \mathrm{BMI} \leq 24.002$ for the middle tertile, and $24.003 \leq \mathrm{BMI}$ for the upper tertile in women. When the prevalence of each dyslipidemic index was compared across the Sasang constitutional types within each tertile, in the lower tertile, difference was detected in the high TG, high LDL-chol, and low HDL-chol indices, with the lowest prevalence rates found in the SE group. In the middle tertile, difference was detected in the high TG and low HDL-chol indices, in which the prevalence rates were higher in order of TE $>$ SY $>$ SE. In the higher tertile, difference was detected in the high TG and low HDL-chol indices, in which the prevalence rates were similarly higher in order of TE $>$ SY $>$ SE.

\section{Comparison of lipid profiles across the different constitutional types}

As displayed in Table 2, 3, the T-chol, TG, and HDL-chol levels did not show constitution type $\times$ BMI group interaction. T-chol and TG levels were both higher in order of $\mathrm{TE}>\mathrm{SY}>\mathrm{SE}$, while HDL-chol level was lower in order of $\mathrm{TE}<\mathrm{SY}<\mathrm{SE}$.

\section{Comparison of the odds ratio for the dyslipidemic indices in each Sasang constitutional type}

The risk for each dyslipidemic index (high $\mathrm{T}$-chol, high TG, high LDL-chol, and low HDL-chol as defined by NCEP-ATP III criteria) was found to vary across the different Sasang constitutional types, as displayed in Table 4. In the 'high TG' index and the 'low HDL-chol' index, the TE group showed the greatest odds ratio compared to the SE group. In the "high LDL-chol' index, the SY group showed greater odds ratio compared to the SE group. In the 'high $\mathrm{T}$-chol' index, no significant difference in the odds ratios was detected.
Table 4. Odds Ratio for the Dyslipidemic Indices in Each Sasang Constitutional Type

\begin{tabular}{ll}
\hline \multicolumn{1}{c}{ Variable } & \multicolumn{1}{c}{$\begin{array}{c}\text { Odds ratio } \\
(95 \% \text { confidence interval })^{\mathrm{a}}\end{array}$} \\
\hline $\begin{array}{l}\text { High T-chol }(\geq 240 \mathrm{mg} / \mathrm{dl})^{\mathrm{b}} \\
\text { SE type }\end{array}$ & 1 \\
SY type & $1.116(0.928 \sim 1.341)$ \\
TE type & $1.210(0.995 \sim 1.472)$ \\
High TG $(\geq 200 \mathrm{mg} / \mathrm{dl})^{\mathrm{b}}$ & 1 \\
SE type & $1.716 \mathrm{c}(1.411 \sim 2.087)$ \\
SY type & $2.021 \mathrm{c}(1.650 \sim 2.475)$ \\
TE type & 1 \\
High LDL-chol $(\geq 160 \mathrm{mg} / \mathrm{dll})^{\mathrm{b}}$ & \\
SE type & $1.229 \mathrm{~d}(1.006 \sim 1.501)$ \\
SY type & $1.190(0.962 \sim 1.472)$ \\
TE type & 1 \\
Low HDL-chol $(<40 \mathrm{mg} / \mathrm{dll})^{\mathrm{b}}$ & \\
SE type & $1.195 \mathrm{~d}(1.033 \sim 1.381)$ \\
SY type & $1.414 \mathrm{c}(1.212 \sim 1.649)$ \\
TE type & \\
\hline
\end{tabular}

T-chol: total cholesterol, SE: Soeum, SY: Soyang, TE: Taeeum, TG: triglyceride, LDL-chol: low density lipoprotein cholesterol, HDL-chol: high density lipoprotein cholesterol,

${ }^{a}$ Analyzed after adjusting for sex, age, and body mass index. ${ }^{b}$ Based on NCEP-ATP III criteria definition of dyslipidemia: T-chol $\geq 240$ $\mathrm{mg} / \mathrm{dll}, \mathrm{TG} \geq 200 \mathrm{mg} / \mathrm{dl}$, LDL-chol $\geq 160 \mathrm{mg} / \mathrm{dl}, \mathrm{HDL}-\mathrm{chol}<40 \mathrm{mg} / \mathrm{dl}$. ${ }^{\circ}$ Significant difference among constitutional groups, $P<0.01$. ${ }^{d}$ Significant difference among constitutional groups, $\mathrm{P}<0.05$.

\section{Discussion}

\section{Brief summary and discussion}

To summarize, dyslipidemic risk varied across different constitutional types, with 'high TG' and 'low HDL-chol' risk highest in the TE type and lowest in the SE type and 'high LDL-chol' risk higher in the SY type compared to the SE type.

The gender and BMI distribution variation among different Sasang constitution types is actually a well-documented phenomenon. Previous reports unanimously report similar gender distribution, with higher male percentage observed in the SY type and higher female percentage in the SE type ${ }^{19)}$. More remarkably, the BMI distribution profiles are also established, with many studies reporting obesity-prone characteristics in the TE type $\mathrm{e}^{20,21)}$. The prevalence and risk rates for other chronic diseases are also known to vary among the Sasang 
constitution types, such as for hypertension ${ }^{16)}$, type 2 diabetes mellitus ${ }^{15)}$, insulin resistance ${ }^{14)}$, and ischemic cerebrovascular diseases ${ }^{22)}$. Similarly, the results of this study indicate constitutional type-specific lipid profiles and dyslipidemic risk, specifically that the TE constitution-type trait can act as an independent risk factor for dyslipidemia.

Of the dyslipidemic indices explored in this study, the risk for 'high LDL-chol' showed equivocal patterns. The inter-constitutional type difference for the 'high LDL-chol' trait (TE>SY >SE) was visible only in the lower tertile, and the inter-type difference was attenuated with change in tertile class. This could be interpreted as implying that the constitutional type-related difference in 'high LDL-chol' risk was only visible in the normal weight group and attenuated with increase in weight. Also, while the risk for 'high TG' and 'low HDL-chol' indices varied across all three constitutional types, the 'high LDL-chol' risk differed among only the SY and SE types, placing weight on the dyslipidemic indices of 'high TG' and 'low HDL-chol'. Although the results were somewhat equivocal for LDL-chol (the primary target in current lipid control therapy), the HDL-chol and TG are also well-known independent risk factors for CHD that are included as secondary therapy targets. Indeed, guidelines recommend a complete lipoprotein profiling that includes $\mathrm{T}$-chol, TG, LDL-chol, and HDL-chol to assess the CHD risk. Also, TG and HDL-chol levels are taken into consideration when deciding on the LDL-chol goals, following the basic principles of 'risk-reduction' therapy that adjusts the intensity of lipid control strategy to a person's risk status ${ }^{1,23-26)}$. The heightened propensity of 'high TG' and 'low HDL-chol' found in the TE constitutional type compared to other types could add to the CHD risk, on par with the increased risk of arteriosclerotic sequelae in $\mathrm{TE}$ types reported in literature ${ }^{27,28)}$.

\section{Context and implications}

One of the highlighted features of this study is the constitutional type-based approach to dyslipidemia. Even compared to the ethnic or sociodemographic studies, the constitutional approach is more patientspecific and intimately attentive to patient details, conferring an advantage in the time- and cost-effective prediction of dyslipidemic risk and the targeting of lipid control strategies. Also, the typology-based methodology is a potent tool in that because the physiological patterns, pathological presentation, and optimal therapeutic approach for each constitutional type is already established, the attending physician is instantly led to an efficient and effective therapeutic protocol once the constitutional type has been decided.

\section{Limitations}

The largest limitation of this study is the insufficient information collected on $\mathrm{CO}^{-}$-morbidities and medications that could influence the lipid metabolism and profiles in the subjects. Though the sample size was large and the results could be construed as representing the cross-section of the population regardless of the presence or absence of lipid control intervention, this lack of data on medical history is a great limitation of this study and should be taken into account when interpreting its results.

\section{Conclusion}

To conclude, this study shows the new possibilities that the lipid profiles and dyslipidemic risk can differ across Sasang constitutional types, showing constitution type-specific patterns. The TE type shows high dyslipidemic risk for elevated TG and low HDL-chol, thusly demonstrating that a specific Sasang constitution type can be a trait that can act as an independent risk factor for dyslipidemia and other cardiovascular or 
chronic diseases.

\section{Acknowledgements}

This research was supported by Basic Science Research Program through the National Research Foundation of Korea (NRF) funded by the Ministry of Science, ICT and Future Planning (No. 2011-0012113).

\section{References}

1. National Cholesterol Education Program (NCEP) Expert Panel on Detection E, and Treatment of High Blood Cholesterol in Adults (Adult Treatment Panel III). Third report of the National Cholesterol Education Program (NCEP) expert panel on detection, evaluation, and treatment of high blood cholesterol in adults (Adult Treatment Panel III) final report. Circulation. $2002 ; 106(25): 3143-421$.

2. Grundy SM, Cleeman JI, Merz CN, Brewer HB Jr, Clark LT, Hunninghake DB, et al. Implications of recent clinical trials for the National Cholesterol Education Program Adult Treatment Panel III guidelines. Circulation. $2004 ; 110(2)$ : 227-39.

3. Smith SC Jr, Allen J, Blair SN, Bonow RO, Brass LM, Fonarow GC, et al. AHA/ACC guidelines for secondary prevention for patients with coronary and other atherosclerotic vascular disease: 2006 update: endorsed by the National Heart, Lung, and Blood Institute. Circulation. 2006 ; 113(19) : 2363-72.

4. Donin AS, Nightingale CM, Owen CG, Rudnicka AR, McNamara MC, Prynne CJ, et al. Ethnic differences in blood lipids and dietary intake between UK children of black African, black Caribbean, South Asian, and white European origin: the Child Heart and Health Study in England (CHASE). Am J Clin Nutr. 2010 ; 92(4) : 776-83.

5. Zweifler RM, McClure LA, Howard VJ, Cushman M, Hovater MK, Safford MM, et al. Racial and geographic differences in prevalence, awareness, treatment and control of dyslipidemia: the reasons for geographic and racial differences in stroke (REGARDS) study. Neuroepidemiology. 2011 ; 37(1) : 39-44.

6. Goff DC Jr, Bertoni AG, Kramer H, Bonds D, Blumenthal RS, Tsai MY, et al. Dyslipidemia prevalence, treatment, and control in the Multi-Ethnic Study of Atherosclerosis (MESA): gender, ethnicity, and coronary artery calcium. Circulation. 2006 ; $113(5): 647-56$.

7. Deboer MD. Ethnicity, obesity and the metabolic syndrome: implications on assessing risk and targeting intervention. Expert Rev Endocrinol Metab. 2011 ; 6(2) : 279-89.
8. Brunzell JD, Davidson M, Furberg CD, Goldberg RB, Howard $\mathrm{BV}$, Stein $\mathrm{JH}$, et al. Lipoprotein management in patients with cardiometabolic risk: consensus statement from the American Diabetes Association and the American College of Cardiology Foundation. Diabetes Care. 2008 ; 31(4) : 811-22.

9. Genest J, McPherson R, Frohlich J, Anderson T, Campbell N, Carpentier A, et al. 2009 Canadian Cardiovascular Society/Canadian guidelines for the diagnosis and treatment of dyslipidemia and prevention of cardiovascular disease in the adult: 2009 recommendations. Can J Cardiol. 2009 ; 25(10) : 567-79.

10. Gaziano JM, Gaziano TA. Simplifying the approach to the management of dyslipidemia. JAMA. 2009 ; 302(19) : 2148-9.

11. Kim JY, Duong DP. Sasang constitutional medicine as a holistic tailored medicine. Evid Based Compl Alt. 2009 ; 6(Suppl 1) : 11-9.

12. Lee J, Jung Y, Yoo J, Lee E, Koh B. Perspective of the human body in Sasang constitutional medicine. Evid Based Compl Alt. 2009 ; 6(Suppl 1) : 31-41.

13. Lee SW, Jang ES, Lee J, Kim JY. Current researches on the methods of diagnosing Sasang constitution: an overview. Evid Based Compl Alt. 2009 ; 6(Suppl 1) : 43-9.

14. Choi K, Lee J, Yoo J, Lee E, Koh B, Lee J. Sasang constitutional types can act as a risk factor for insulin resistance. Diabetes Res Clin Pract. 2011 ; 91(3) : e57-60.

15. Lee TG, Koh B, Lee S. Sasang constitution as a risk factor for diabetes mellitus: a cross-sectional study. Evid Based Compl Alt Med. 2009; 6 Suppl 1 : 99-103.

16. Lee J, Lee J, Lee E, Yoo J, Kim Y, Koh B. The Sasang constitutional types can act as a risk factor for hypertension. Clin Exp Hypertens. 2011 ; 33(8) : 525-32.

17. Kim S, Lee J, Park G, Jeong Y, Lee S, Song I. A study on responses to the questionnaire based on revised Sasang Constitution Classification II (QSCCII+). J Sasang Const Med. $2001 ; 13(3): 15-22$.

18. WHO Expert Consultation. Appropriate body-mass index for Asian populations and its implications for policy and intervention strategies. Lancet. 2004 ; 363(9403) : 157-63.

19. Lee T, Hwang M, Ham T, Lee S, Choe B, Koh B, et al. A study on the distribtional rate of Sasangin in Korea. J Sasang Const Med. $2005 ; 17(3): 12-21$.

20. Lee K, Seok J, Kim S, Kim Y. A Case-control study on risk factors of obese patients of each Sasang constitution. J Sasang Const Med. 2007 ; 19(2) : 94-112.

21. Kim E, Kim J. A clinical study on the Sasang constitution and obesity. J Sasang Const Med. 2004 ; 16(1) : 100-11.

22. Joo J, Kim K. Angiotensin converting enzyme (ACE) gene polymorphism and Sasang constitution in patients with cerebral infarction. J Sasang Const Med. 2002 ; 14(1) : 132-9. 
23. Rubenfire M, Brook RD, Rosenson RS. Treating mixed hyperlipidemia and the atherogenic lipid phenotype for prevention of cardiovascular events. Am J Med. $2010 ; 123(10)$ : 892-8.

24. Robinson JG, Wang SF, Smith BJ, Jacobson TA. Meta-analysis of the relationship between non-high-density lipoprotein cholesterol reduction and coronary heart disease risk. J Am College Cardiol. 2009 ; 53(4) : 316-22.

25. Millan J, Pinto X, Munoz A, Zuniga M, Rubies-Prat J, Pallardo LF, et al. Lipoprotein ratios: physiological significance and clinical usefulness in cardiovascular prevention. Vasc Health
Risk Manag. 2009; $5:$ 757-65.

26. Menown IB, Murtagh G, Maher V, Cooney MT, Graham IM, Tomkin G. Dyslipidemia therapy update: the importance of full lipid profile assessment. Adv Ther. 2009 ; 26(7) : 711-8.

27. Lee J, Kim S, Lee E, Song I, Koh B. A study on the correlation of metabolic syndrome and intima-media thickness of common carotid artery with sasang constitution. J Sasang Const Med. $2007 ; 19(1): 148-59$.

28. Han D, Yu J, Koh S, Park J. Relationship between intima media thickness of common carotid artery and Sasang constitution. J Sasang Const Med. 2011 ; 23(2) : 218-29.

\title{
사상체질이 이상지질혈증의 위험인자가 될 수 있는가?
}

\author{
이지원, 장현수, 박병주, 이의주, 고병희, 이준희
}

경희대학교 한의과대학 사상체질과

목적: 본 연구는 사상체질과 이상지질혈증의 상관관계 및 사상체질이 이상지질혈증의 위험요인이 될 수 있는가를 탐색하는 데 목 적이 있다.

방법: 본 연구는 의무기록을 바탕으로 한 후향적 단면조사연구로, 2007년 5월부터 2010년 6월까지 서울 소재 경희의료원 건강증진 센터에 내원한 건강검진 수진자 17,069 명의 의무기록을 조사하여 사상체질진단검사 결과 및 생화학검사 결과 등이 확인된 15,250 명을 대상으로 사상체질과 이상지질혈증 간의 상관관계를 조사하였다.

결과: 총 콜레스테롤과 중성지방은 체질량지수(body mass index, BMl)를 보정한 상태에서 태음인, 소양인, 소음인 등의 순서로 높 았고, 고밀도 콜레스테롤은 소음인, 소양인, 태음인 순서로 높았다. 연령, 성별, BMI 등을 보정한 상태에서 '높은 중성지방'에 대한 odds ratio는 소음인에 비해 소양인이 1.716 (1.411 2.087), 태음인이 2.021 (1.650 2.475)이었으며, '높은 저밀도콜레스테롤'에 대한 odds ratio는 소음인에 비해 소양인이 1.229 (1.006 1.501)였고, '낮은 고밀도 콜레스테롤'에 대한 odds ratio는 소음인에 비 해 소양인이 1.195 (1.033 1.381), 태음인이 1.414 (1.212 1.649)였다.

결론: 사상체질에 따라 일부 이상지혈증의 분포 및 odds ratio에 유의한 차이가 있었고, 이에 따라 사상체질이 이상지질혈증의 위험 요인이 될 수 있는 가능성을 찾을 수 있었다. 